
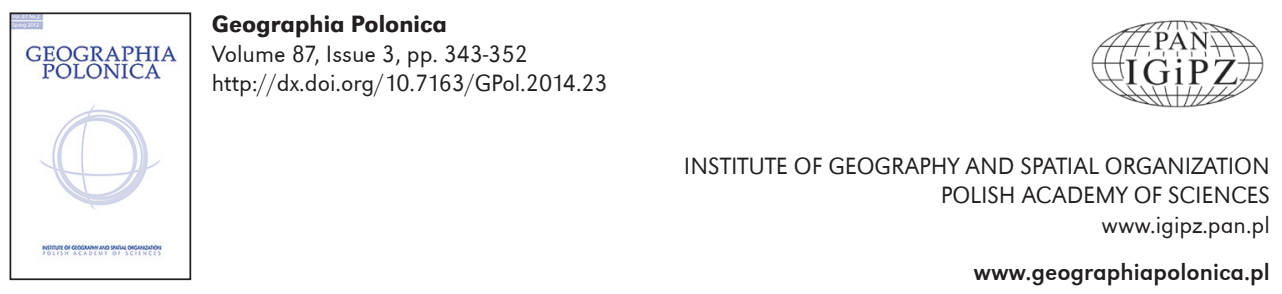

\title{
TOURISM GEOGRAPHIES: CONNECTIONS WITH HUMAN GEOGRAPHY AND EMERGING RESPONSIBLE GEOGRAPHIES
}

\author{
Jarkko Saarinen \\ Vice-President of the International Geographical Union \\ University of Oulu \\ Department of Geography \\ P.O. Box 3000, Fl-90014, Oulu: Finland \\ University of Johannesburg \\ School of Tourism and Hospitality \\ PO Box 524, Auckland Park: South Africa \\ e-mail: jarkko.saarinen@oulu.fi
}

\begin{abstract}
Geographical study of tourism has a long history and well-established relationship with human geography. The purpose of this paper is thus to discuss the role and nature of tourism geographies in relation to human geography, by focusing on connections/disconnections between the fields. The issue of responsibility, representing one of the latest major focal points in geographical tourism studies of tourism, is also overviewed in relation to sustainability. It is concluded that, although the field of tourism geographies has become versatile and closer to the conceptual and theoretical understandings of human geography, there are increasing processes challenging the academic production and circulation system of international tourism geographies, which scholars need to deal with.
\end{abstract}

\section{Key words}

tourism $\bullet$ tourism geography $\bullet$ sustainability $\bullet$ responsibility $\bullet$ academic capitalism

\section{Introduction: Tourism}

The scale of the global tourism industry is vast. It is estimated that tourism contributes approximately $9 \%$ to global production and employs more than 220 million people across the globe (Sofield 2003; Scheyvens 2011). As a result, tourism and tourists have become characteristic features of global markets and contemporary societies and they influence various planning and development strategies. Indeed, due to its massive scale, potential and growing importance the industry is increasingly used as a medium for various socio-economic 
and political aims. Basically, goals relating to promoting tourism as an activity have been argued with reference to the business, regional and sustainable development dimensions (Saarinen \& Rogerson 2014), which are interrelated and dependent on each other in the long-term perspective.

Tourism as a business emphasises possibilities for private entrepreneurship and profitmaking. It is an industry-oriented view whereby development is defined on corporate terms and scales. In contrast, the regional dimension focuses on a wider spatial scale; and the industry is regarded as a potentially viable tool for regional development and employment creation (Müller \& Jansson 2007). Currently many governments and various international and regional development agencies are promoting the industry with a view to catalysing regional economic development (Hall 2000; Rogerson 2006). While development is defined economically, it also involves - or should include - wider regional development goals and indicators. Since the 1990s, however, the development aspects in tourism have been focused more clearly on broader aspects of wellbeing, quality of life and the environment, by reference to the idea of sustainable development (Butler 1999). From that perspective the industry is seen as a potential tool by which to use and manage destination resources in environmentally, socio-culturally and economically sustainable ways.

These general dimensions are evident in past and present research on tourism geographies. Some of the fundamental questions in geographical tourism research have been focuses on such issues as: the factors making places attractive to potential visitors; the ways in which places become known to people as tourist destinations; the ways in which tourism creates impacts and changes places and the ways in which these changes and impacts can be managed and cultivated in a regionally beneficial and sustainable way. In this respect, tourism is characteristically a geographical phenomenon, and geography has a prominent position in the analysing of tourism and its nature, processes, interactions, impacts and future. While the analysis has characteristically been characteristically empirical, geographical studies can also make novel theoretical and conceptual contributions to the field. Indeed, as sociologist Urry (1995: 1) noted: "almost all the major social and cultural theories bear upon the explanation of place". From a geographical point of view, tourism can be seen as a movement or mobility between origins, i.e. sending regions and destinations (Leiper 1979, 1990). This mobility involves various impacts and relations and experiences of the environment and of being a tourist (or a host) (Gordon \& Goodall 2000). In this respect an important aspect of tourism is consumption; tourism is a sector or cluster of the economy/economies which creates tourist commodities and spaces of consumption. In a way, the whole tourist destination can be seen as a commodity produced for non-local people to consume (Saarinen 2004). This non-locality is an integral part of tourism. Most definitions of tourism recognise it as a short-term leisure and recreation activity for people who are away from their normal environment of residence and work, with the intention of returning to their home community within a few days, weeks or months (Hall \& Page 1999: 3-5). Tourism may also be developed and controlled by non-local actors and investors, creating well-being and growth or inequalities and skewed development from a local point of view. In addition, from a local community perspective tourism may represent non-local value systems (Squire 1994; Scheyvens 2011).

Geographical study of tourism has often been seen to be intertwined with the field of economic geography. Indeed, geography was long placed under its umbrella; e.g. as regards the work of the International Geographical Union (IGU) Commission and Study Group. While the links between tourism and economic geography are historically eminent and contemporary prominent, e.g. in relation to emerging evolutionary economic geography (Martin \& Sunlay 2006; Ma \& Hassink 2013; Brouder 2014), tourism geographies also have a long history and relationship 
with the wider field of human geography, and since the late 1960s it has evolved towards its present status as a distinct sub-field of geographical research. The purpose of this paper is to discuss the role and connections of tourism geographies in relation to human geography. Recently, there have been several detailed thematic and regional reviews on the nature and state of tourism geographies (Butler 2004; Gibson 2008ab, 2010; Hall \& Page 2009; Hall 2013; Saarinen 2013). Therefore, instead of (re)categorising past and current studies, this paper aims to focus on general connections and disconnections between tourism geographies and human geography. Finally, there will be a brief focus on issues of sustainability and responsibility, representing some of the latest major paradigms in tourism geographies.

\section{The changing focus in geographical tourism studies}

Tourism research and geography is not being pursued in an academic or societal vacuum. On the contrary, the research happens in, and is influenced by, certain time-space contexts. This transforming contextual nature of tourism research, in general, is demonstrated in Jafari's (1990, 2001) 'platform analysis'. According to him there have been several platforms or phases to tourism research, including tourism geographies. The earliest phase, the advocacy platform, represents an economic growth orientation towards the tourism industry. Research activities have focused on the economic role, potential and impacts of tourism, with studies driven by the related questions and needs of the industry, with a view to its growth being boosted and the constraints on growth examined.

The advocacy approach was hegemonic until the 1970s and was supported by the economic growth and increasing wellbeing and leisure time in the Western world, especially. However, its role was in part challenged from the 1960s onwards, and especially in the 1970s, by the cautionary platform. The cautionary views were warning that along with growth and positive economic impacts (for the industry), there are costs to the environment, local cultures and communities. The cautionary views also reflect the contextual discussions in other fields of academic research, as well as environmental policies and international strategies seeking to deal with the pollution of the environment (Saarinen 2006). In addition, some critical views were based on global-scale discussions concerning the political and economic imbalances to NorthSouth relations (Britton 1982), as well as obvious inequalities of tourism growth in the Third World (Young 1973; Britton 1991). Tourism was seen as a highly political activity with deep connections to the world economy.

These two views reasoning academic tourism research in geography and tourism studies were in general in conflict; representing opposites as regards argumentation. However, they shared a similar principal view that took the existing nature of the tourism industry for granted. If simplified, tourism growth and the industry were either seen as dichotomically good or bad. Contrast with these views the third platform, the adaptive phase which seeks to develop alternative models in tourism development (Jafari 1990). The argumentation in research was based on the need to mitigate the negative and enhance the positive impacts and elements in tourism (Saarinen 2013). This had connections with the emerging ecological thinking as regards consumption, and the evolution of the green movement in the 1980s. These were manifested in tourism operations through the creation of terms and ideas such as ecotourism (Mowhforth \& Munt 1998; Fennell 1999). In the 1990s, along with the emergence of sustainable development policies, the adaptive phase evolved towards sustainable tourism thinking in geographical research. The latter idea of sustainable tourism aims at social, cultural, economic and environmental responsibility, as well as better management models and practices in tourism development (Hunter 1997). The final phase to Jafari's (2001) platforms is the knowledge-based approach. As the term indicates, it argues for the role and value of academically-driven and 
sound research on tourism and its changes and impacts. Tourism is understood as a growing global-scale industry and a form of culture which will evidently have increasing impacts on its operational (and wider) environment in the future. Thus, if the impacts of the megascale industry are to be better managed, better knowledge, information, models, and theories are seen to be needed in tourism geographies (Hall \& Page 1999, 2009; Butler 2004).

While these different platforms in tourism research can be seen as phases based on different kinds of contextual issues and processes at the time of their emergence, they can all still be traced among the approaches of current tourism geographies. In addition to the previous platform categories, Holden (2003) and Macbeth (2005) have proposed a new dimension to the evolution of academic tourism research: they see an emerging and urgent need for a new kind of ethics in tourism operations and development (see also Fennell 2006). This evolving ethical or responsibility platform re-emphasises the adaptive dimension, albeit in a different way. Its perspective is based more on biocentric and environmental viewpoints as, in the end, the adaptive platform represents the industry-oriented view (Saarinen 2006). In contrast to that, the ethical platform emphasises the rights of nature, the limits to growth and responsibility in tourism. It also involves ideas aiming to re-structure local-global relations in tourism development, e.g. in relation to benefit sharing, empowerment and equity. These aims have close connections with the original idea of sustainable development and emerging geographies of responsibility (Saarinen 2014), which both fall within critical discussions on tourism in human geography.

\section{Tourism studies and human geography}

Change is typical of tourism as a spatial and social phenomenon (Butler 1980), and the transforming nature and impacts have interested geographers for almost as long as geographical tourism studies have been conducted. Gilbert (1939, 1949), for example, studied the development of seaside and inland resorts in the United Kingdom. Christaller (1963) also strived to subject the development of tourism to geographical study. For him, the typical course of development for a new tourist destination in a peripheral area followed the next pattern: "Painters search out untouched unusual places to paint. Step by step the place develops as a so-called artist colony. Soon a cluster of poets follows, kindred to the painters; then cinema people, gourmets, and the jeunesse dorée. The place becomes fashionable and the entrepreneur takes note. The fisherman's cottage, the shelter-huts become converted into boarding houses and hotels come on the scene. Meanwhile the painters have fled and sought out another periphery - periphery as related to space, and metaphorically, as 'forgotten' places and landscapes. Only the painters with commercial inclination who like to do well in business remain; they capitalise on the good name of this former painter's corner and on the gullibility of tourists. More and more townsmen choose this place, now en vogue and advertised in the newspapers. Subsequently the gourmets, and all those who seek real recreation, stay away. At last the tourist agencies come with their package rate travelling parties; now, the indulged public avoids such places. At the same time, in other places the cycle occurs again; more and more places come into fashion, change their type, turn into everybody's tourist haunt." (Christaller 1963: 103).

For Christaller, tourism was a phenomenon typical of peripheries. However, many peripheral areas are today integrated into the cores of global economies and larger networks, by way of the development of tourism and related mobilities. Indeed, global compression of time and space, with its increase in reflexive global consciousness, has been influencing tourism for a long time: in tourism distant places and regions have always communicated in matters of growth, 
development and exchange, and have been dependent on each other, thanks to the movement of people, capital, ideas, values, goods, etc. (Saarinen 2001). The economic significance of tourism and the fact that tourism continues to grow mean that new destinations, attractions and facilities are being created constantly. Places and regions are being planned, transformed and managed with a view to more tourists, related businesses, investors and public resources being attracted. Whole countries and national economies can be highly dependent on the needs of modern tourists, and the associated industry. In addition, tourism is or can be a major element constituting the way in which we see our environment, other places and cultures, and the way in which 'we and others' see and represent 'us and them' and related identities (Munt \& Mowforth 1998; Del Casino \& Hanna 2000; Saarinen 2004). All this makes the current situation an exciting and important one for the geographical study of tourism (Williams \& Shaw 2000).

The growth in the societal and economic significance of tourism has encouraged the development and institutionalisation of tourism studies within and in relation to human (and obviously economic) geography. Internationally, this has been evident since the 1960s (Wolfe 1964, 1967; Mitchell 1969; Mayer-Arendt 2000), leading towards a distinct sub-field of tourism geography, contemporarily called tourism geographies. The role of the geographical approach has been further emphasised in tourism research as, during the last three decades, terms like space, place and region have become a part of the conceptual armament of tourism studies and the social sciences in general (Giddens 1979; Urry 1990, 1995; Rojek 1993). This 'spatial turn' of social and cultural studies, or "spatialisation of social theory" as Featherstone and Lash (1995: 1) put it, originates from theoretical discussions that took place in the 1980s and early 1990s. A key message from this spatialisation aspect to social theory and tourism studies has been that spatial reality is produced, reproduced and differentiated in various locales by social forces and structures (Chouinard 1997). At the same time, these spatial contexts have a temporal dimension and changing nature, which is highly evident in the tourism phenomenon. Thus, the ongoing spatial and social differentiation in tourism and societies in general, has been seen, not solely as a one-way street resulting from economic, socio-cultural and political structures, but also as an outcome of the influential role of space and places in the production and reproduction of social reality (Massey 1984; Urry 1990).

The spatial turn has been reflected in international geographical research into tourism (Gordon \& Goodall 2000). It has also afforded a partial answer for a problematic issue in tourism studies and geographies noted by Mitchell (1984). She argued that the geographical examination of tourism has generally stressed "the unique case rather than the general situation" and theoretisation (Mitchell 1984: 5). The lack of (social) theoretisation was probably both a condition for and a consequence of the individualistic perspectives criticised by Mitchell. Squire (1994) has further stated that geographical tourism research has not in the past been sufficiently influenced by theoretical or methodological developments in other fields of human geography, or in the social sciences in general (Del Casino \& Hanna 2000). Similarly, Britton (1991: 456) argued that "The geography texts on tourism offer little more than cursory and superficial analyses of how the tourism industry is structured and regulated by the classic imperatives and laws governing capitalists accumulation". While this was probably still the case in the 1980s and turn of the 1990s, the situation has changed in tourism geographies (Hall \& Page 1999, 2009; Gibson 2008a, 2008b, 2010). Current research focuses more critically on such issues as globalisation, neoliberal politics, socio-economic encounters and increasing circulation of capital and inequalities (Scheyvens 2011; Hall 2013), among many others. 
Squire (1994) originates the past theoretical and conceptual problems of geographical tourism studies within the whole institution of geography. She evaluates the interaction between tourism and human geographers as minimal and underdeveloped academically, and claims that both sides are inclined to be passive. This lack of academic interaction is manifested in many textbooks, as very few key sources in human and cultural geography mention the term tourism in their index or discuss it as an issue (Hall \& Page 1999) although the phenomenon is claimed as one of the largest and fastest-growing economic sectors, with a multitude of socio-cultural dimensions and impacts restructuring our and other environments and worldviews. Similarly, quite a few textbooks on tourism geography are influenced by contemporary theories and key texts in human geography. However, in recent decades there have been a growing number of exceptions (e.g. Shaw \& Williams 1994; Mowforth \& Munt 1998; Hall 2005; Scheyvens 2011). Indeed, Hall and Page (1999), for example, see positive signs of change when it comes to the role of tourism in academic geography.

Firstly, there is "major growth in the number and quality of publications by tourism and recreation geographers" (Hall \& Page 1999: 20), and there is also one dedicated high level journal for geographical studies on tourism: Tourism Geographies published by Taylor and Francis. Secondly, there are increasing attempts to provide a stronger and wider theoretical basis for tourism geographies, which aims to be informed by and able to contribute to contemporary social theory and human geography. However, there is still also a need for work on tourism within human geography, and for an understanding of spatiality within tourism (Lew 1999; Gordon \& Goodall 2000; Saarinen 2001). The subsequent section deals with sustainability and emerging new responsibility in tourism, these being among the key themes in studies on geographical tourism and the use of tourist spaces. A brief discussion in relation to tourism production and consumption is provided.

\section{Sustainability and emerging responsible geographies of tourism development}

Since the 1990s, sustainable development has emerged as a hegemonic paradigm in tourism operations, with increasing calls for responsibility to extend beyond economic issues alone (Saarinen 2014). Recently sustainability in tourism has been linked visibly to the ideas of responsible and ethical consumption (Goodwin \& Francis 2003; Carrier 2010). This has been evident in various high-level policy aims and discussions focusing on the reduction of global poverty and inequalities (Saarinen \& Rogerson 2014). The Secretary-General of the UNWTO has, for example, stated that the global tourist industry could play a major role in the achievement of the United Nations Millennium Development Goals (UN MDGs) by 2015 (UNWTO 2006). Indeed, the industry is actively framed as responsible for various aims and impacts on the global scale. This emerged idea of responsible tourism refers, in general, to tourism development that aims to make places better for people to live in and visit (Goodwin 2009). While the concept of responsible tourism is usually understood as a specific and separate form, it has many connections with the aims of sustainable tourism development. Conceptually it is rather challenging to "distinguish responsible tourism from the concept of sustainable tourism" (Sharpley 2013: 385).

Although responsibility in tourism is built on similar grounds to sustainability, with overlapping principles and practices, there are contextual differences (Saarinen 2014). The emerging responsibility discourse also originates from neoliberal 'self-organising' modes of new governance (Scheyvens 2011). In addition, in human geographical research the responsibility discourse is seen as a part of a so-called 'moral turn' (Smith 1997, see also Proctor 1998). From the human geographical research perspective, Lawson (2007, 2009) has emphasised the need for care to be extended, not only to 'our own', 
but also to strangers from afar. This resonates well with the recent discussions on responsible tourism, and especially volunteer tourism (Sin 2010). However, while responsibility has emerged as an ethical platform in tourism geographies and tourism studies, it in general involves similar challenges similar to those defining sustainability. In relation to sustainable tourism especially, these have gained wide discussion elsewhere (Butler 1999; Sharpley 2000; Saarinen 2006). In the context of responsibility, the questions on whose responsibility and for whom we are responsible are seen as highly critical (Saarinen 2014; Sharpley 2013).

In this respect there are two intertwined views on responsibility in tourism production and consumption (Saarinen 2014): (I) Consumers are seen to lead the industry pro-actively towards more sustainable operations, due to better and increasing environmental awareness in societies, and/or (II) the industry is said to be adopting the principles and practices of responsibility and are therefore seen to be progressing towards more responsible modes of tourism (Sharpley 2013). The consumer dimension to responsibility is seen as progress towards increasing demand for sustainable products, based on changing modes of consumption that relate to new tourism and greater environmental responsibility on the part of 'new tourists' (Poon 1995). In addition, the assumed enhanced environmental awareness of consumers is seen to trigger the supply of sustainable tourism products (Orams 1997). The producer dimension is manifested in initiatives such as the Tourist Operators Initiative to Sustainable Tourism (TOI 2013). Like many other similar initiatives, this set, self-organized rules and offers indicators by which tourism businesses may manage their responsibilities.

The intertwined logic of progressive responsibility in tourism consumption and production is widely noted. However, previous studies indicate challenges to both views of responsibility. Sharpley (2013) indicates how most academic studies show that, despite a 'greening' of attitudes, environmental concerns still remain low on the list of tourists' consumption priorities. There are segments of 'new responsible tourists', but their place in the overall picture of global tourism remains marginal. Similarly, there has been progress with tourism businesses adopting responsible or sustainable tourism principles, but the adoption process has been slow and the used and tailor-made principles are often said to be industry-oriented ('flexible'), serving the industry's economic needs to a greater degree than social and environmental issues and responsibilities (Hunter 1997; Buckley 1999). In addition, only a relatively small number of businesses and related agencies are aiming beyond the basic legal obligations (Sharpley 2013).

\section{Conclusion}

Geographical studies on tourism have grown considerably in number over the past two decades. At IGU meetings, for example, the number of sessions devoted to tourism geographies is usually among the greatest. At the same time, research has become more versatile, and scholarly activities resonate well with the other fields of human geographies and the social sciences. Tourism geographers are increasingly contributing academic research beyond the sub-discipline. As Gibson (2008a: 418) noted, tourism geography is "on the whole more cosmopolitan" than many other parts of geography, with "its own geography of production and circulation".

However, there are also elements that increasingly challenge the academic production and circulation system of international tourism geographies in a form of academic capitalism, corporate universities and publication rankings (Hall 2010; Saarinen 2013). As in many other disciplines, in (human) geography the academic rankings favour publishing in international peer-reviewed journals. While there are positive elements accruing from the attendant quality control and collegial communication systems, the journals are often categorised based on the views from the core areas of the discipline. Thus, the top journals in which international tourism 
geographers usually publish their research are not often ranked on the same high level as the top or mid-level journals in human geography in general. If this uneven and biased structure of evaluations and prestige in human geographical publishing remains, it will weaken the sub-discipline in the future.

In order to avoid these potentially very negative consequences of the current biased mode of evaluations, assessment scales and journal rankings, tourism geographers should be more active in promoting their research not least within human geography (Hall \& Page 1999; Saarinen 2013). This may denote

\section{References}

BRITTON S., 1982. The political economy of tourism in the Third world. Annals of Tourism Research, vol. 9, no. 4, pp. 331-358.

BrITTON S., 1991. Tourism, capital, and place: Towards a critical geography of tourism. Environment and Planning D: Society and Space, vol. 9, no. 4, pp. 451-478.

BUCKLEY R., 1999. An ecological perspective on carrying capacity. Annals of Tourism Research, vol. 26, no. 3, pp. 705-708.

BUtLER R., 1980. The concepts of a tourist area cycle of evolution: Implications for management of resources. Canadian Geographer, vol. 24, no. 1, pp. 5-12.

BUTLER R., 1999. Sustainable tourism: A state-ofthe-art review. Tourism Geographies, vol. 1, no. 1, pp. 7-25.

BUtLeR R., 2004. Geographical research on tourism, recreation and leisure. Tourism Geographies, vol. 6, no. 2, pp. 143-162.

CARRIer J., 2010. Protecting the environment the natural way: Ethical consumption and commodity fetishism. Antipode, vol. 42, no. 3, pp. 672-689.

Chouinard V., 1997. Structure and agency: Concrete concepts in human geography. The Canadian Geographer, vol. 41, no. 4, pp. 963-977.

Christaller W., 1963. Some considerations of tourism locations in Europe: The peripheral regions - under-developed countries - recreation a more active need to publish in the core journals of human geography in future, but also an aim to find and create synergies and contacts between the conceptual and theoretical aspects and developments in human and tourism geographies. In addition, the focus areas such as critical sustainability and emerging responsible or ethical tourism geographies can offer a platform that empowers geographers of tourism to contribute to the wider field of human geography and, thus, maintain the historically fruitful connections and interrelatedness with the core disciplinary areas of geography.

areas. Regional Science Association, vol. 12, no. 1, pp. 95-105.

Del Casino V. J. JR., Hanna S.P., 2000. Representation and identity in tourism map spaces. Progress in Human Geography, vol. 24, no. 1, pp. 23-46.

Featherstone M., Lash S., 1995. Globalisation, modernisation and the spatialisation of social theory [in:] M. Featherstone, S. Lask (eds.), Global modernity. London: Sage Publications, pp. 1-24.

Fennell D., 1999. Ecotourism. New York: Routledge.

Fennell D., 2006. Tourism ethics. Clevedon: Channelview.

GIBSON C., 2008a. Geographies of tourism: International leasing geography? Progress in Human Geography, vol. 32, no. 1, pp. 1-16.

GIBSON C., 2008b. Locating geographies of tourism. Progress in Human Geography, vol. 32, no. 3, pp. 407-422.

GIBSON C., 2010. Geographies of tourism:(Un)ethical encounters. Progress in Human Geography, vol. 34, no. 4, pp. 521-527.

Giddens A., 1979. Central problems in social theory: Action, structure and contradiction in social analyses. London: Macmillan.

Gilbert E.W., 1939. The growth of island and seaside health resorts in England. Scottish Geographical Magazine, vol. 55, no. 1, pp. 16-35.

GILBERT E.W., 1949. The growth of Brighton. The Geographical Journal, vol. 114, no. 1-3, pp. 30-52. 
Goodwin H., 2009. Contemporary policy debates: Reflections on 10 years of pro-poor tourism. Journal of Policy Research in Tourism, Leisure and Events, vol. 1, no. 1, pp. 90-94.

Goodwin H., Francis J., 2003. Ethical and responsible tourism: Consumer trends in the UK. Journal of Vacation Marketing, vol. 9, no. 3, pp. 271-284.

Gordon I., Goodall B., 2000. Localities and tourism. Tourism Geographies, vol. 2, no. 3, pp. 290-311.

Hall C.M., 2000. Tourism planning. Essex: Pearson.

Hall C.M., 2005. Tourism: Rethinking the social science of mobility. Essex: Pearson.

Hall C.M., 2010. Academic capitalism, academic responsibility and tourism academics: or, the silence of the lambs? Tourism Recreation Research, vol. 35, no. 3, pp. 298-301.

HaLl C.M., 2013. Framing tourism geography: notes from the underground. Annals of Tourism Research, 43, pp. 601-623.

Hall C.M., PAGE S., 1999. The geography of tourism: environment, place and space. London and New York: Routledge.

Hall C.M., PAGE, S. 2009. Progress in tourism management: From the geography of tourism to geographies of tourism - a review. Tourism Management, vol. 30, no. 1, pp. 3-16.

HOLDEN A., 2003. In need of new environmental ethics for tourism. Annals of Tourism Research, vol. 30, no. 1, pp. 94-108.

Hunter C.J., 1995. On the need to re-conceptualize sustainable tourism development. Journal of Sustainable Tourism, vol. 3, no. 3, pp. 155-165.

JAFARI J., 1990. Research and scholarship: The basis of tourism education. Journal of Tourism Studies, vol. 1, no. 1, pp. 33-41.

JAFARI J., 2001. The scientification of tourism [in:] V.L. Smith, M. Brent (eds.), Hosts and guests revisited. New York: Cognizant Communications, pp. 28-41.

LAWSON V., 2007. Geographies of care and responsibility. Annals of Association of American Geographers, vol. 97, no. 1, pp. 1-11.

LAWSON V., 2009. Instead of radical geography, how about caring geography? Antipode, vol. 41, no. 1, pp. 210-213.

LEIPER N., 1979. The framework of tourism. Annals of Tourism Research, vol. 6, no. 4, pp. 390-407.
LEIPER N., 1990. Tourist attraction system. Annals of Tourism Research, vol. 17, no. 3, pp. 367-384.

LEW A., 1999. Editorial: a place called tourism geographies. Tourism Geographies, vol. 1, no. 1, pp. 1-2.

Ma M., Hassink R., 2013. An evolutionary perspective on tourism area development. Annals of Tourism Research, vol. 41, pp. 89-109.

MACBETH J., 2005. Towards an ethics platform for tourism. Annals of Tourism Research, vol. 32, no. 4, pp. 962-984.

Martin R.L., Sunlay P.J., 2006. Path dependency and regional economic evolution. Journal of Economic Geography, vol. 6, no. 4, pp. 395-438.

MASSEY D., 1984. Spatial divisions of labour: Social structures and the geography of production. London: Macmillan.

Mayer-Arendt K.J., 2000. Commentary: tourism geography as the subject of North American doctoral dissertations and master thesis. Tourism Geographies, vol. 2, no. 2, pp. 140-156.

MitCheLL L., 1969. Recreational geography: evolution and research needs. The Professional Geographer, vol. 21, no. 2, pp. 117-119.

MitCHELL L., 1984. Tourism research in the United States: A geographic perspective. GeoJournal, vol. 9, no. 1, pp. 5-15.

Mowforth M., Munt I., 1998. Tourism and sustainability: A new tourism in the Third World. London: Routledge.

Muller D., Jansson B. (eds.), 2007. Tourism in peripheries. Wallingford: Cabi.

Orams M., 1997. The effectiveness of environmental education: Can we turn tourists into 'greenies'? Progress in Tourism and Hospitality Research, vol. 3, no. 4, pp. 295-306.

Poon A., 1993. Tourism, technology and competitive strategies. Wallingford: CAB International.

PROCTOR J.D., 1998. Ethics on geography: Giving moral form to the geographical imagination. Area, vol. 30, no. 1, pp. 8-18.

Rogerson C.M., 2006. Pro-poor local economic development in South Africa: The role of propoor tourism. Local Environment, vol. 11, no. 1, pp. 37-60.

Rojek C., 1993. Ways of escape. Modern transformations in leisure and travel. London: Macmillan.

SAARINEN J., 2001. The transformation of a tourist destination - theory and case studies on the 
production of local geographies in tourism in Finnish Lapland. Nordia Geographical Publications, vol. 30, no. 1, pp. 1-105.

SaARInen J., 2004. 'Destinations in change': The transformation process of tourist destinations. Tourist Studies, vol. 4, no. 2, pp. 161-179.

SAARINEN J., 2006. Traditions of sustainability in tourism studies. Annals of Tourism Research, vol. 33, no. 4, pp. 1121-1140.

SAARINEN J., 2013. Nordic tourism geographies: from regional analysis to diversity in Research [in:] J. Wilson, S.A. Clave (eds.), Geographies of tourism: European tourism geographies. Tourism Social Science Series, 19. Bingley: Emerald, pp. 37-55.

SAARINEN J., 2014. Critical sustainability: Setting the limits to growth and responsibility in tourism. Sustainability, vol. 6, no. 11, pp. 1-17.

SaArinen J., Rogerson C. M., 2014. Tourism and them millennium development goals: Perspectives beyond 2015. Tourism Geographies (accepted).

SCHEYVENS R., 2011. Tourism and poverty. London: Routledge.

SHARPLEY R., 2000. Tourism and sustainable development: Exploring the theoretical divide. Journal of Sustainable Tourism, vol. 8, no. 1, pp. 1-19.

SHARPLEY R. 2013. Responsible tourism: Whose responsibility? [in:] A. Holden, D. FenNeLL (eds.), The Routledge Handbook of Tourism and Environment. London: Routledge, pp. 382-391.

ShaW G., Williams A., 1994. Critical issues in tourism: A geographical perspective. Oxford: Blackwell Publishers.
SIN H.L., 2010. Who are we responsible to? Local's tales of volunteer tourism. Geoforum, vol. 41, no. 6, pp. 983-992.

SмITH D.M., 1997. Geography and ethics: A moral turn? Progress in Human Geography, vol. 21, no. 4, pp. 583-590.

SofIELD T., 2003. Empowerment for sustainable tourism development. Oxford: Pergamon.

SQUIRE S., 1994. Accounting for cultural meanings: The interface between geography and tourism studies re-examined. Progress in Human Geography, vol. 18, no. 1, pp. 1-16.

TOI, 2013. Tourist operators initiative to sustainable tourism. www.toinitiative.org [6 November 2013].

UNWTO 2006. UNWTO's declaration on Tourism and the Millennium Goals: Harnessing Tourism for the Millennium Development Goals. Madrid: UNWTO.

URRY J., 1990. The tourist gaze: Leisure and travel in contemporary societies. London: SAGE.

URRY J., 1995. Consuming places. London: Routledge.

Williams A., ShaW G., 2000. Guest editorial: Tourism geography in a changing world. Tourism Geographies, vol. 2, no. 3, pp. 239-240.

Wolfe R., 1964. Perspective on outdoor recreation: A bibliographical survey. The Geographical Review, vol. 54, no. 2, pp. 203-238.

WolfE R., 1967. Recreational travel: The new migration. Geographical Bulletin, vol. 9, no. 1, pp. 73-79.

Young G., 1973. Tourism: Blessing or blight? Harmondsworth: Penguin. 